\title{
OBITUARIES
}

Lord Stopford, K.B.E., F.R.S.

John Sebastian BaCh Stopford was born near Wigan on June 25, 1888, and died on March 6, 1961, at Arnside, Westmorland.

He was educated at Liverpool College, Manchester Grammar School and the University of Manchester, graduating M.B., Ch.B. with honours in 1911, after gaining several distinetions and prizes during his medical course. After serving as a house surgeon at Rochdale Infirmary and assistant medical officer at Manchester Royal Infirmary, he became, in 1912, a demonstrator in anatomy in the University of Manchester. He was promoted lecturer in 1915 and in the same year he received the degree of M.D. with a Gold Medal for a thesis of outstanding merit on "The Arteries of the Pons and Medulla". He succeeded to the Manchester chair of anatomy in 1919 on the resignation of Prof. (later Sir) Grafton Elliot Smith, and in December 1934 he was appointed vicechancellor in succession to Sir Walter Moberley. He combined his duties as vice-chancellor and professor of anatomy until 1938, when he resigned his chair and was appointed to a personal chair of experimental neurology.

His ability as a scientist was recognized by his election to the fellowship of the Royal Society in 1927 , and he was the first Manchester medical graduate to achieve this high honour. Under the inspiration of Elliot Smith, his research work was predominantly neurological, and he collaborated successfully with his surgical colleagues (Sir Harry Platt, Sir Geoffrey Jefferson and Profs. E. D. Telford and John Morley) in the elucidation of various problems. His work can be divided roughly into three phases-his investigations on the blood supply of the brain, his anatomical and clinical studies on sensation, based mainly on the observation of many patients with peripheral nerve injuries, and his researches on the structure and function of various parts of the autonomic nervous system. He published more than sixty papers and an important monograph on "Sensation and the Sensory Pathways" (1930), besides contributing sections to several anatomical text-books. As vice-chancellor he was unable to indulge his flair for correlating basic and clinical research, but had he continued as a scientist he would undoubtedly have enhanced his already high reputation.

In a short notice one cannot even mention all that Stopford did for education and his University; but he was the best vice-chancellor Manchester has ever had and according to Sir Hector Hetherington (1956) "the best of us all" (the "all" refers to the members of the Committee of Vice-Chancellors and Principals). His worth was recognized nationally by his appointment as chairman, vice-chairman or member of such influential bodies as the General Medical Council and the University Grants Committee, the Commonwealth Fund, the Nuffield Foundation, the Interdepartmental Committee on Medical Schools, the Universities Bureau of the British Empire and the Council of the Royal College of Physicians, while locally he served as chairman of the Manchester Regional Hospital Board (1948-53), of the John Rylands
Library, of the Royal College of Music, and on many other bodies. He was awarded honorary degrees by the Universities of Dublin, Leeds, Cambridge, Liver. pool, Durham and Manchester, and honorary fellowships by the Royal College of Physicians and Royal College of Surgeons. He was knighted in 1941, created a K.B.E. in 1955, and he was included in the first list of life peers (1958).

He was a fine and imaginative teacher who helped to rescue anatomy from the topographical morass into which it had fallen, and who did much to close the gap which had developed between the basic medical sciences and clinical practice. He was a pioneer in the use of radiological methods in teaching living anatomy, and he was the first to take over from physiology the full responsibility for teaching histology. Both as a professor and vice-chancellor his sympathy with students and their problems was evident; and he was appreciated as highly by his colleagues in the Arts and other Faculties as by those in his own profession. His familiarity with education and research in all their manifold aspects was utilized, as the abbreviated list of his appointments given above indicates, by many Government and other bodies; and he was the chief inspiration for many of the far-sighted reforms in medical education recommended in the Goodenough Report.

$\mathrm{He}$ married Lily Allan, another Manchester medical honours graduate, in 1916, and they had one son. Theirs is the greatest loss; but those who served under him honour the memory of a distinguished scientist and supreme administrator and marvel that one who had gained so many honours could yet remain so human, humble and kind.

G. A. G. Mitchell

\section{Miss Ethel F. Bellamy}

The death of Ethel F. Bellamy on December 7 at the age of seventy-eight removes one of the last of those self-trained and dedicated workers who have done so much for astronomy and seismology in Great Britain. Miss Bellamy went to the Oxford University Observatory in $\mathbf{1 8 9 9}$ as a personal assistant to her uncle, the late F. A. Bellamy, and was able to relieve him of some part of the work in the preparation of the Oxford zones of the Astrographic Catalogue. On the completion of these zones and under the direction of Prof. H. H. Turner, Miss Bellamy then undertook the reduction of the measures for the Vatican zones, work for which she was awarded a commemorative silver medal by the Pope in 1920 .

At the end of the First World War, Prof. Turner had agreed to continue at Oxford the seismological work of John Milne. Miss Bellamy assisted Turner, and in this connexion spent some months in 1919 at Shide in the Isle of Wight in charge of Milne's instruments. This responsibility she continued when the improved Milne-Shaw seismographs were transferred first to the Boys's basement in the old Clarendon Laboratory and ultimately in 1928 to the University Observatory itself. Her great contribution to seismology lay, however, in the preparation of the Inter. national Seismological Summary (prior to 1923 the 